\title{
Follicle-stimulating hormone mediates the consumption of serum-derived glycogen by bovine cumulus-oocyte complexes during in vitro maturation
}

Ludymila F. Cantanhêde ${ }^{1}$, Cristiane T. Santos-Silva², Marcelo T. Moura ${ }^{1}$ D, José C. Ferreira-Silva ${ }^{1}$, Júnior M. B. Oliveira” ${ }^{\# 1}$ Daniel N. A. Gonçalves ${ }^{1} \mathbb{D}$, Álvaro A. C. Teixeira², Valéria Wanderley-Teixeira² and Marcos A. L. Oliveira ${ }^{1}$

1. Department of Veterinary Medicine, Federal Rural University of Pernambuco - UFRPE, Recife 52171900, Brazil;

2. Department of Morphology and Animal Physiology, Federal Rural University of Pernambuco - UFRPE, Recife 52171900, Brazil.

Corresponding author: Marcelo T. Moura, e-mail: marcelotmoura@gmail.com

Co-authors: LFC: lud_furtado@hotmail.com, CTS: cristiane.thalita@ufpe.br, JCF: carlos.ztec@gmail.com,

JMBO: deceased, DNAG: daniel.nagon@gmail.com, AACT: alvaro.teixeira@ufrpe.br, vW: valeria.wanderley@ufrpe.br, MALO: maloufrpe@gmail.com

\#Deceased on 22-04-2021

Received: 09-05-2021, Accepted: 23-08-2021, Published online: 24-09-2021

doi: www.doi.org/10.14202/vetworld.2021.2512-2517 How to cite this article: Cantanhêde LF, Santos-Silva CT, Moura MT, Ferreira-Silva JC, Oliveira JMB, Gonçalves DNA, Teixeira ÁAC, Wanderley-Teixeira V, Oliveira MAL (2021) Follicle-stimulating hormone mediates the consumption of serum-derived glycogen by bovine cumulus-oocyte complexes during in vitro maturation, Veterinary World, 14(9): 2512-2517.

\begin{abstract}
Background and Aim: Oocyte in vitro maturation (IVM) is an appealing approach for several assisted reproductive technologies and dissecting oocyte maturation. Nonetheless, IVM leads to lower developmental competence and usually relies on undefined, serum-containing media. Therefore, biochemical profiling aimed to explore fluctuations in IVM media content during the acquisition of oocyte developmental competence.
\end{abstract}

Materials and Methods: Bovine cumulus-oocyte complexes (COCs) underwent IVM in TCM199 medium with Earle's salts, supplemented with $2.0 \mathrm{mM} \mathrm{L}$-glutamine, $10 \%$ fetal bovine serum, antibiotics, and $0.05 \mathrm{IU} / \mathrm{mL}$ porcine folliclestimulating hormone $(\mathrm{FSH}+)$ or vehicle control $(\mathrm{CTL})$ medium for $22 \mathrm{~h}$.

Results: FSH withdrawal (CTL) diminished several processes associated with the acquisition of oocyte developmental competence, such as reduced cumulus cell expansion, diminished estradiol synthesis (FSH+: $116.0 \pm 0.0 \mathrm{pg} / \mathrm{mL}$ vs. CTL: $97.6 \pm 18.0 \mathrm{pg} / \mathrm{mL}$ ), and lower oocyte nuclear maturation rate (FSH+: $96.47 \%$ vs. CTL: $88.76 \%$ ). Fresh media formulations (i.e., TCM199 with FSH or vehicle) were indistinguishable under biochemical profiling threshold conditions. Biochemical profiling showed similar total protein and lipid concentrations between groups. Further, total sugar concentrations diminished from fresh media to their post-IVM counterparts, albeit in an FSH-independent manner. Glycogen concentrations remained unaltered after IVM within CTL media, albeit were substantially lower after IVM under FSH+ conditions.

Conclusion: FSH mediates the consumption of serum-derived glycogen by bovine COCs during IVM and implies that serum-free media should contain increased glucose concentrations to facilitate the acquisition of oocyte developmental competence.

Keywords: biomolecules, cattle, developmental competence, gonadotropin, granulosa, sera.

\section{Introduction}

Oocytes must undergo nuclear and cytoplasm changes during the acquisition of developmental competence, which is the potential to sustain early embryogenesis compatible with full-term development. Oocyte maturation includes nuclear processes such as germinal vesicle breakdown, nucleolus diffusion, chromatin condensation, and extrusion of the first polar body [1]. The cytoplasmic alterations associated with developmental competence correlate with

Copyright: Cantanhêde, et al. Open Access. This article is distributed under the terms of the Creative Commons Attribution 4.0 International License (http://creativecommons.org/licenses/ by/4.0/), which permits unrestricted use, distribution, and reproduction in any medium, provided you give appropriate credit to the original author(s) and the source, provide a link to the Creative Commons license, and indicate if changes were made. The Creative Commons Public Domain Dedication waiver (http:// creativecommons.org/publicdomain/zero/1.0/) applies to the data made available in this article, unless otherwise stated. structural changes and biochemical processes [2-4]. Cytoplasmic changes during the acquisition of developmental competence include protein synthesis [5], protein post-translational modifications [2-4], reorganization of cellular organelles [6], and activation of $\mathrm{Ca}^{2+}$-release mechanisms [7].

Both nuclear and cytoplasmic changes during the acquisition of developmental competence in vivo rely on the follicular microenvironment, which contemplates the follicular fluid and paracrine factors from multiple neighboring cell types $[8,9]$. Oogenesis demands several components of the follicular fluid, which includes energy substrates, amino acids, hormones (i.e., steroid and pituitary), cytokines, and growth factors [9-12]. The follicle-stimulating hormone (FSH) is one of the better understood factors to promote oocyte developmental competence $[8,13,14]$. For instance, estradiol is a steroid hormone found in 
the follicular fluid, and its concentration increases during follicle development $[15,16]$. This estradiol increase spawns from FSH-mediated cumulus cell signaling [14]. In sum, oocytes attain developmental competence by a plethora of interactions among cumulus cells, the oocyte, and the follicle environment $[8,9,17]$.

Oocyte in vitro maturation (IVM) recapitulates, at least partially, cellular and molecular processes that occur during oocyte maturation in vivo [17-19]. Despite efficient nuclear maturation under most experimental IVM conditions [20,21], oocytes subject to IVM display lower developmental competence than those matured in vivo [17]. Oocytes under IVM fail to acquire full cytoplasmic maturation, and IVM media must upgrade to improve developmental competence. Synthetic IVM media allowed successful livestock oocyte IVM and in vitro embryo production (IVP) [17]. Basal media (e.g., TCM199) used for IVM and IVP have formulations optimized for somatic cell culture [22]. Therefore, these basal media require substantial supplementation with known factors to promote oocyte maturation and the acquisition of developmental competence during IVM. FSH is one of the essential components of IVM media $[8,14]$. Numerous reports have functionally demonstrated the importance of FSH for the acquisition of oocyte developmental competence [14,23-26]. Since FSH regulates (directly and indirectly) several metabolic processes in oocytes and cumulus cells during IVM $[8,14]$, FSH withdrawal may reveal insights into cumulus-oocyte complexes (COCs) metabolic activities during IVM. This approach would allow distinguishing between processes required for developmental competence (using IVM medium supplemented with FSH) from those happening under basal needs for cellular physiology (under FSH-free IVM medium).

Therefore, the study aimed to perform biochemical profiling under FSH-containing and FSH-free IVM conditions and prospecting modulations in IVM media associated with the acquisition of oocyte competence in cattle.

\section{Materials and Methods}

\section{Ethical approval}

The experiment was approved by the Ethics Committee (Comissão de Ética e Experimentação Animal - CEUA) from the Universidade Federal Rural de Pernambuco (Protocol 060/2013).

\section{Oocyte maturation}

The IVM of bovine COCs was performed as previously described by Moura et al. [27]. Briefly, ovary collection was at local abattoirs (Pernambuco state, Brazil) and transported in saline solution $(0.9 \% \mathrm{NaCl})$ containing $10 \mathrm{IU} / \mathrm{mL}$ penicillin and $10 \mu \mathrm{g} / \mathrm{mL}$ streptomycin (Gibco, Waltham, MA, USA) at $35^{\circ} \mathrm{C}$ within $3 \mathrm{~h}$ after slaughter. The COCs were retrieved from 2 to $8 \mathrm{~mm}$ follicles using $10 \mathrm{~mL}$ syringes coupled with $19 \mathrm{G}$ needles into H-IVM medium (TCM199 medium with Hank's salts [Sigma-Aldrich, St. Louis, MO, USA] supplemented with $2 \mathrm{mM}$ L-glutamine [SigmaAldrich, St. Louis, MO, USA], 10\% fetal bovine serum [FBS] [Gibco, Waltham, MA, USA], and $0.05 \mathrm{mg} / \mathrm{mL}$ gentamicin sulfate [Gibco, Waltham, MA, USA]).

Retrieved COCs with homogeneously granulated oocyte cytoplasm and at least three complete cumulus cell layers were used for IVM [27]. The COCs were randomly distributed into FSH-containing IVM medium (FSH+; $0.05 \mathrm{IU} / \mathrm{mL}$ pFSH - Sigma-Aldrich, St. Louis, MO, USA) or the vehicle-containing IVM medium (control - CTL). The IVM medium was formulated with TCM199 with Earle's salts supplemented with $2 \mathrm{mM}$ L-glutamine, $10 \% \mathrm{FBS}, 10 \mathrm{IU} / \mathrm{mL}$ penicillin, and $10 \mu \mathrm{g} / \mathrm{mL}$ streptomycin (Gibco, Waltham, MA, USA). All IVM media were adjusted for $\mathrm{pH}$ (7.27.4 ) and osmolarity (260-280 mOsm). Experimental groups were formed by pools of 20-25 COCs [28] per $150 \mu \mathrm{L}$ of IVM medium and further incubated with $5 \% \mathrm{CO}_{2}$, saturated humidity at $38.5^{\circ} \mathrm{C}$ for $22 \mathrm{~h}$. The media after IVM were transferred to microtubes and centrifuged at 2,000 g for $5 \mathrm{~min}$. Moreover, the supernatant was collected and stored at $-20^{\circ} \mathrm{C}$, alongside with fresh media (i.e., not used for IVM) for further estradiol concentration analysis profiling.

\section{Analysis of oocyte nuclear maturation}

The COCs were denuded after $22 \mathrm{~h}$ of IVM. All COCs were initially washed and kept in $0.2 \%$ hyaluronidase (Sigma-Aldrich, St. Louis, MO, USA), then further incubated in hyaluronidase solution and gentle pipetting for $5 \mathrm{~min}$. Oocytes were washed from cumulus cells in H-IVM media. The nuclear maturation efficiency was determined by the number of oocytes with visible polar bodies.

\section{Estradiol analysis}

The estradiol concentration was determined by the immunoassay Access 2 (Beckman Coulter, Brea, CA, USA) at the CENAPESQ Center, UFRPE. The analysis was carried out with the Estradiol 2 X 50 DET - BC kit and the Estradiol CAL S0-S5 Access.

\section{Biochemical profiling}

Biochemical profiling was carried out using a Bel photonics SP 2000 UV spectrophotometer (ABM Italy, Milan, Italy). The total protein analysis was performed with the Bradford assay with the Coomassie blue [29]. A $100 \mu \mathrm{L}$ volume of each sample was mixed with $5 \mathrm{~mL}$ Bradford solution for $2 \mathrm{~min}$ and determined in the spectrophotometer with a $595 \mathrm{~nm}$ reads.

The total glycogen, lipid, and sugars concentrations were determined by the method described by Santos Silva et al. [29]. A volume of $200 \mu \mathrm{L}$ sodium sulfate and $800 \mu \mathrm{L}$ chloroform-methanol (1:1) were mixed with $200 \mu \mathrm{L}$ of each IVM media sample. After homogenizing, samples were centrifuged at $2000 \mathrm{~g}$ for $2 \mathrm{~min}$. The precipitate was used for glycogen analysis, while the supernatant was transferred to another microtube for the assessment of sugars and lipids. The total lipid content was determined 
by spectrophotometry using phosphoric acid and vanillin [29], while total sugar content and glycogen concentration were analyzed using sulfuric acid and anthrone [29]. Absorbance was read at $625 \mathrm{~nm}$, and five replicates were used in duplicate for each IVM media (FSH supplemented - fresh and after IVM; vehicle control - fresh and after IVM).

\section{Statistical analysis}

The estradiol data $(\mathrm{pg} / \mathrm{mL})$ were initially subject to logarithmic transformation of the base 10 , while the glycogen and sugars data were subject to radical and logarithmic transformations, respectively. All continuous data were described as means, standard deviation, and range. The assessment of the data for normality was determined by the Shapiro-Wilk test. The data were subject to the F-test or ANOVA, while the mean comparisons were carried out using Tukey's HSD test or the Student-Newman-Keuls test [30]. The efficiency of oocyte nuclear maturation rates was analyzed by the Chi-square test. The IBM SPSS Statistics software version 23.0 (IBM, Armonk, NY, USA) was used for the statistical analysis. The significance level was $5 \%$.

\section{Results}

To demonstrate the potential of the experimental design, cumulus cell expansion, estradiol synthesis, and oocyte nuclear maturation were recorded after IVM of bovine COCs with or without FSH supplementation (Figure-1). The cumulus cell expansion was substantially more intense in the $\mathrm{FSH}+$ group than in the non-treated CTL (Figure-1). Moreover, FSH deprivation diminished nuclear maturation efficiency determined by polar body extrusion (Table-1). Estradiol concentration measurement demonstrated FSH-mediated modulation of cumulus cell physiology (Table-2). The presence of FSH in IVM media formulation did not affect estradiol levels in fresh media (i.e., FSH+ and CTL). Further, IVM media from the CTL group showed similar concentrations between the fresh and post-IVM samples. In turn, estradiol level increased in FSH+ media after IVM in comparison to its fresh counterpart sample (Table-2).

Biochemical profiling in maturation media (before and after IVM in both FSH+ and CTL groups) prospected modulations in composition associated with the acquisition of oocyte developmental competence (Table-3). The screening on IVM media samples analyzed total protein, lipids, sugars, and glycogen concentrations. IVM media formulation $(\mathrm{FSH}+$ or CTL) did not lead to any variation in biochemical parameters (i.e., below detection threshold). Both total protein and lipid contents were similar between samples, irrespectively of FSH supplementation or IVM. Sugar content diminished after IVM, albeit in an FSH-independent manner. Fluctuations in glycogen concentration between fresh CTL media and its postIVM sample did not reach the statistical threshold.

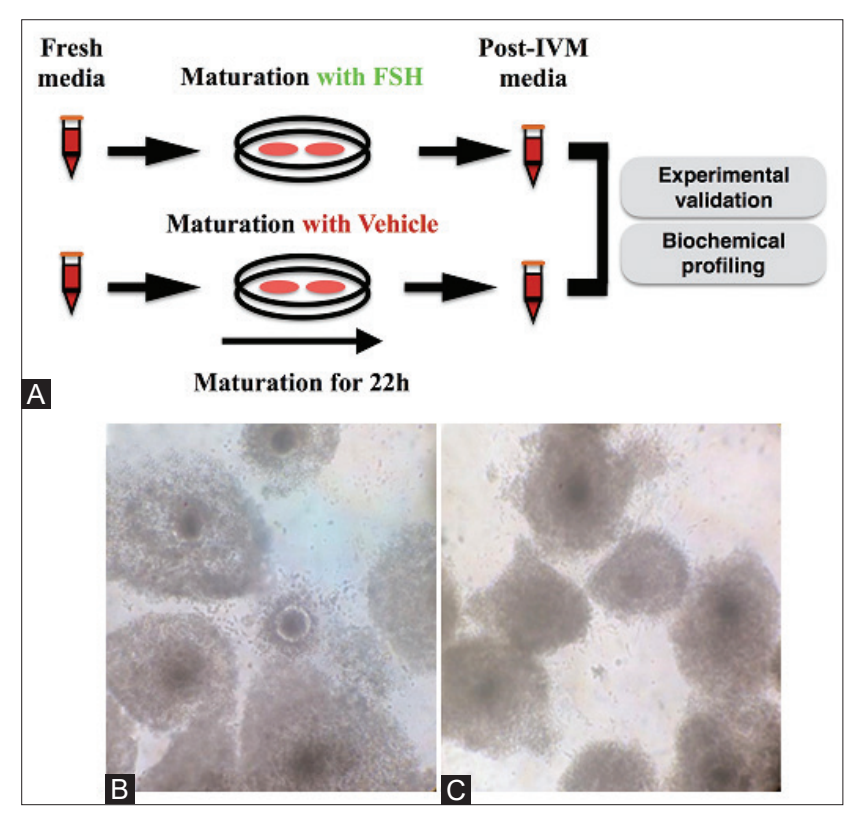

Figure-1: Experimental design and cumulus cell expansion analysis under varying follicle-stimulating hormone (FSH) conditions. (A) In vitro maturation (IVM) media collection before and after oocyte IVM for $22 \mathrm{~h}$. Oocytes harvested for experimental design validation and IVM media were subject to both estradiol quantification (experimental design validation) and composition analysis (biochemical profiling). Expansion of cumulus cells of cumulus-oocyte complexes after $22 \mathrm{~h}$ of IVM under FSH containing $\mathrm{FSH}+(\mathrm{B})$ and control vehicle-containing IVM media (C).

Table-1: Nuclear maturation rates after exposure of bovine cumulus-oocyte complexes to FSH supplementation $(\mathrm{FSH}+)$ or its vehicle $(\mathrm{CTL})$ during in vitro maturation for $22 \mathrm{~h}$.

\begin{tabular}{lccc}
\hline Group & $\begin{array}{c}\text { Cumulus-oocyte } \\
\text { complexes }\end{array}$ & $\begin{array}{c}\text { Oocytes with } \\
\text { polar body }\end{array}$ & $\begin{array}{c}\text { Maturation } \\
\text { rate (\%) }\end{array}$ \\
\hline FSH & 170 & 164 & $96.47^{\mathrm{A}}$ \\
CTL & 178 & 158 & $88.76^{\mathrm{B}}$ \\
\hline
\end{tabular}

Five replicates. Follicle-stimulating hormone $\mathrm{FSH}=\mathrm{FSH}$-containing IVM media.

$\mathrm{CTL}($ control $)=$ Vehicle-containing IVM media Different superscript letters (A, B) denote statistical difference by the Chi-square test $(p<0.05)$

Nonetheless, the glycogen concentration lowered after IVM under FSH+ conditions, thus suggesting FSH-mediated consumption (Table-3).

\section{Discussion}

Repeated collection of immature oocytes from donor cows largely increases the number of transferable IVP embryos per cow in any given stretch of time [17]. However, this increased number of embryos per cow is counterbalanced by the diminished developmental competence of IVM-derived oocytes (and resulting IVP embryos) in comparison to oocytes matured in vivo [17,31]. Therefore, IVM conditions must improve to mimic in vivo conditions and enhance oocyte developmental competence.

In this work, the effect of FSH on the expansion of cumulus cells, estradiol production, and oocyte nuclear maturation was observed ex vivo, thus reinforcing the seminal effects of this hormone on cellular 
Table-2: Estradiol concentration ( $\mathrm{pg} \mathrm{mL}^{-1}$ ) before and after exposure of bovine cumulus-oocyte complexes to FSH or its vehicle (control) during in vitro maturation for $22 \mathrm{~h}$.

\begin{tabular}{lcccccc}
\hline Statistical & & FSH & & \multicolumn{2}{c}{ Control } \\
\cline { 2 - 4 } & $\begin{array}{c}\text { Before in vitro } \\
\text { maturation }\end{array}$ & $\begin{array}{c}\text { After in vitro } \\
\text { maturation }\end{array}$ & & $\begin{array}{c}\text { Before in vitro } \\
\text { maturation }\end{array}$ & $\begin{array}{c}\text { After in vitro } \\
\text { maturation }\end{array}$ \\
\hline Mean $\pm \mathrm{SD}$ & $58.3 \pm 8.6^{\mathrm{B}}$ & $116.0 \pm 50.8^{\mathrm{A}}$ & & $56.0 \pm 0.0^{\mathrm{B}}$ & $97.6 \pm 18.0^{\mathrm{B}}$ \\
Range & $49.0-66.0$ & $79.0-174.0$ & $56.0-56.0$ & $79.0-115.0$ \\
\hline
\end{tabular}

$\mathrm{SD}=$ Standard deviation; different superscript letters $\left({ }^{A}, \mathrm{~B}\right)$ denote statistical difference $(\mathrm{p}<0.05)$. F-test, Tukey's HSD test, and Student-Newman-Keuls test. FSH=Follicle-stimulating hormone

Table-3: Media composition before and after exposure of bovine cumulus-oocyte complexes to FSH or its vehicle (control) during in vitro maturation for $22 \mathrm{~h}$.

\begin{tabular}{lccccc}
\hline Content & & FSH & & \multicolumn{2}{c}{ Control } \\
\cline { 2 - 3 } \cline { 5 - 6 } & $\begin{array}{c}\text { Before in vitro } \\
\text { maturation }\end{array}$ & $\begin{array}{c}\text { After in vitro } \\
\text { maturation }\end{array}$ & & $\begin{array}{c}\text { Before in vitro } \\
\text { maturation }\end{array}$ & $\begin{array}{c}\text { After in vitro } \\
\text { maturation }\end{array}$ \\
\hline Protein & $22.0 \pm 1.4^{\mathrm{A}}$ & $22.9 \pm 2.6^{\mathrm{A}}$ & & $21.5 \pm 4.9^{\mathrm{A}}$ & $22.2 \pm 2.9^{\mathrm{A}}$ \\
Lipids & $26.1 \pm 0.7^{\mathrm{A}}$ & $27.0 \pm 2.2^{\mathrm{A}}$ & & $26.2 \pm 3.4^{\mathrm{A}}$ & $25.9 \pm 2.2^{\mathrm{A}}$ \\
Sugars & $146.8 \pm 35.9^{\mathrm{A}}$ & $43.4 \pm 25.9^{\mathrm{B}}$ & & $146.1 \pm 32.6^{\mathrm{A}}$ & $41.3^{\mathrm{A}} \pm 19.1^{\mathrm{B}}$ \\
Glycogen & $14.8 \pm 6.0^{\mathrm{A}}$ & $2.2 \pm 4.1^{\mathrm{B}}$ & & $12.1 \pm 4.9^{\mathrm{A}}$ & $8.9 \pm 5.5^{\mathrm{A}}$ \\
\hline
\end{tabular}

$\mathrm{SD}=$ Standard deviation; different superscript letters $(\mathrm{A}, \mathrm{B})$ denote statistical difference $(p<0.05)$. F-test, Tukey's HSD test, and Student-Newman-Keuls test

hallmarks of oocyte maturation [32-34]. Cumulus cells mediate FSH signaling pathways that contribute to the acquisition of developmental competence [14,35-37]. The gene expression profile and physiology of cumulus cells are subject to extracellular cues and interactions with the oocyte $[38,39]$. When supplemented in IVM media, FSH promotes the increase of cumulus cell expansion [40], resumption of meiosis, and steroid hormone production [41-43].

The experimental approach envisioned that removal of a critical component of the IVM media (i.e., FSH) would render oocytes non-competent and impair biochemical processes required for developmental competence. Further, such condition would reveal processes associated with developmental competence by the analysis of medium composition before and after IVM. The results at the cellular level validated the experimental design and unequivocally allowed to prospect for media compositions fluctuations associated with the acquisition of oocyte developmental competence. Biochemical profiling revealed the dynamic nature of IVM media composition during oocyte IVM.

Total protein and lipid concentrations remained constant among all experimental conditions. Several proteins play pivotal roles during oocyte maturation, such as the proteins that form the maturation promoting factor complex, and signaling pathways such as mitogenic activated protein kinase, epidermal growth factor related, and protein kinase A [5,44-46], respectively. Lipids may be toxic or beneficial during IVM [43,47-49]. The inability to identify differences in total protein and lipid levels may be due to the detection thresholds or a balance between catabolism and anabolism. Additional analyses focusing on candidate proteins/lipids or unbiased genome-wide tools of greater resolution may reveal further details of IVM media modulations.

Sugar levels lowered after IVM in an FSHindependent manner, thus suggesting that IVM actively demands energy substrates, most likely by cumulus cells, due to their abundance and energy substrate preferences. The metabolic demands of bovine COCs also fluctuate during IVM, as demonstrated by measurements of glucose and pyruvate uptake [50]. Cumulus cells rely on different energy sources (glucose, lactate, and pyruvate) for energy metabolism than oocytes (lactate and pyruvate) [51]. In sum, energy supply is paramount for cellular activity during IVM and the acquisition of oocyte developmental competence $[10,52,53]$.

The most notable observation in this study was glycogen consumption under the influence of FSH. Since the basal medium TCM199 does not contain animal-derived components, FBS was the source of glycogen in IVM media. The IVM of COCs under CTL medium conditions did not affect glycogen concentrations, thus ruling out degradation during media incubation in vitro or metabolism by cumulus cells (FSH-independent metabolism). More importantly, this increased energy demand was restricted to the acquisition of oocyte developmental competence. Several non-mammalian model organisms accumulate intracellular glycogen or glycogen phosphatase during oocyte maturation $[53,54]$. Notwithstanding, mural granulosa and cumulus cells of macaque females have the detectable expression of the glycogen phosphatase enzyme $[55,56]$, thus suggesting the potential to convert glycogen into glucose-6-phosphate, which can be later metabolized by glucose metabolism pathways. However, further research should shed light on glycogen concentrations in IVM media, glycogen

Veterinary World, EISSN: 2231-0916 
metabolism by COCs, and its potential connection to the acquisition of oocyte developmental competence.

\section{Conclusion}

FSH mediates the consumption of serum-derived glycogen by bovine COCs during oocyte IVM and implies that serum-free media should contemplate increased energy substrates to compensate for glycogen as an energetic metabolism substrate.

\section{Authors' Contributions}

LFC: Study design, data collection, data interpretation, and manuscript preparation. CTS: Data collection and interpretation. MTM: Study design, data collection, data interpretation, manuscript preparation, and funding support. JCF: Data collection and interpretation. JMBO: Data interpretation and statistical analysis. DNAG: Data collection and interpretation. AACT: Study design, data interpretation, and project supervision. VW: Study design, data interpretation, and project supervision. MALO: Study design, data interpretation, manuscript preparation, funding support, and project supervision. All authors have read and approved the final manuscript.

\section{Acknowledgments}

This work had financial support from Fundação de Amparo a Ciência e Tecnologia de Pernambuco - FACEPE grant (APQ-1101-5.05/15), Pernambuco State, Brazil. MTM is a PNPD/CAPES post-doctorate fellow (Financial code 101).

\section{Competing Interests}

The authors declare no competing interests.

\section{Publisher's Note}

Veterinary World remains neutral with regard to jurisdictional claims in published institutional affiliation.

\section{References}

1. Pan, B. and Li, J. (2019) The art of oocyte meiotic arrest regulation. Reprod. Biol. Endocrinol., 17(1): 8.

2. Richani, D. and Gilchrist, R.B. (2018) The epidermal growth factor network: Role in oocyte growth, maturation and developmental competence. Hum. Reprod. Update, 24(1): 1-14.

3. Dekel, N. (2005) Cellular biochemical and molecular mechanisms regulating oocyte maturation. Mol. Cell. Endocrinol., 234(1-2): 19-25.

4. Roelen, B.A.J. (2019) Bovine oocyte maturation: Acquisition of developmental competence. Reprod. Fertil. Dev., 32(2): 98-103.

5. Sirard, M.A., Richard, F. and Mayes, M. (1998) Controlling meiotic resumption in bovine oocytes: A review. Theriogenology, 49(2): 483-497.

6. Reader, K.L., Stanton, J.L. and Juengel, J.L. (2017) The role of oocyte organelles in determining developmental competence. Biology, 6(3): 35.

7. Wang, W., Day, B.N. and Wu, G. (2003) How does polyspermy happen in mammalian oocytes? Microsc. Res. Tech., 61(4): 335-341.

8. Robker, R.L., Hennebold, J.D. and Russell, D.L. (2018) Coordination of ovulation and oocyte maturation: A good egg at the right time. Endocrinology, 159(9): 3209-3218.

9. Krisher, R.L. (2013) In vivo and in vitro environmental effects on mammalian oocyte quality. Annu. Rev. Anim. Biosci., 1: 393-417.

10. Warzych, E. and Lipinska, P. (2020) Energy metabolism of follicular environment during oocyte growth and maturation. J. Reprod. Dev., 66(1): 1-7.

11. Clarke, H.J. (2018) Regulation of germ cell development by intercellular signaling in the mammalian ovarian follicle. Wiley Interdiscip. Rev. Dev. Biol., 7(1):e294.

12. Liu, Y.X., Zhang, Y., Li, Y.Y., Liu, X.M., Wang, X.X., Zhang, C.L., Hao, C.F. and Deng, S.L. (2019) Regulation of follicular development and differentiation by intra-ovarian factors and endocrine hormones. Front. Biosci., 24(5): 983-993.

13. Sirard, M.A. (2016) Somatic environment and germinal differentiation in antral follicle: The effect of FSH withdrawal and basal LH on oocyte competence acquisition in cattle. Theriogenology, 86(1): 54-56.

14. Assidi, M., Richard, F.J. and Sirard, M.A. (2013) FSH in vitro versus LH in vivo: Similar genomic effects on the cumulus. J. Ovarian Res., 6(1): 68.

15. Liu, W., Xin, Q., Wang, X., Wang, S., Wang, H., Zhang, W., Yang, Y., Zhang, Y., Zhang, Z., Wang, C., Xu, Y., Duan, E. and Xia, G. (2017) Estrogen receptors in granulosa cells govern meiotic resumption of pre-ovulatory oocytes in mammals. Cell Death Dis., 8(3): e2662.

16. Armstrong, D.T., Zhang, X., Vanderhyden, B.C. and Khamsi, F. (1991) Hormonal actions during oocyte maturation influence fertilization and early embryonic development. Ann. N. Y. Acad. Sci., 626(1): 137-158.

17. Lonergan, P. and Fair, T. (2016) Maturation of oocytes in vitro. Annu. Rev. Anim. Biosci., 4: 255-268.

18. Walter, J., Monthoux, C., Fortes, C., Grossmann, J., Roschitzki, B., Meili, T., Riond, B., Hofmann-Lehmann, R., Naegeli, H. and Bleul, U. (2020) Thebovine cumulus proteome is influenced by maturation condition and maturational competence of the oocyte. Sci. Rep., 10(1): 9880.

19. Walls, M.L. and Hart, R.J. (2018) In vitro maturation. Best Pract. Res. Clin. Obstet. Gynaecol., 53(2018): 60-72.

20. Edwards, R.G. (1965) Maturation in vitro of mouse, sheep, cow, pig, rhesus monkey and human ovarian oocytes. Nature, 208(5088): 349-351.

21. Moura, M.T., Sousa, R.V., Oliveira Leme, L. and Rumpf, R. (2008) Analysis of actinomycin D treated cattle oocytes and their use for somatic cell nuclear transfer. Anim. Reprod. Sci., 109(1-4): 40-49.

22. Jimenez, C.R., Araújo, V.R., Penitente-Filho, J.M., de Azevedo, J.L., Silveira, R.G. and Torres, C.A. (2016) The base medium affects ultrastructure and survival of bovine preantral follicles cultured in vitro. Theriogenology, 85(6): 1019-1029.

23. Mao, J., Smith, M.F., Rucker, E.B., Wu, G.M., McCauley, T.C., Cantley, T.C., Prather, R.S., Didion, B.A. and Day, B.N. (2004) Effect of epidermal growth factor and insulin-like growth factor I on porcine preantral follicular growth, antrum formation, and stimulation of granulosa cell proliferation and suppression of apoptosis in vitro. J. Anim. Sci., 82(7): 1967-1975.

24. Thomas, F.H., Ethier, J.F., Shimasaki, S. and Vanderhyden, B.C. (2005) Follicle-stimulating hormone regulates oocyte growth by modulation of expression of oocyte and granulosa cell factors. Endocrinology, 146(2): 941-949.

25. Sakaguchi, K. and Nagano, M. (2020) Follicle priming by FSH and pre-maturation culture to improve oocyte quality in vivo and in vitro. Theriogenology, 150(2020): 122-129.

26. Dias, F.C.F., Khan, M.I.R., Sirard, M.A., Adams, G.P. and Singh, J. (2018) Transcriptome analysis of granulosa cells after conventional vs long FSH-induced superstimulation in cattle. BMC Genomics, 19(1): 258.

27. Moura, M.T., Badaraco, J., Sousa, R.V., Lucci, C.M. and Rumpf, R. (2019) Improved functional oocyte enucleation 
by actinomycin D for bovine somatic cell nuclear transfer. Reprod. Fertil. Dev., 31(8): 1321-1329.

28. van Tol, H.T.A., van Eijk, M.J.T., Mummery, C.L., van den Hurk, C.L. and Bevers, M.M. (1996) Influence of FSH and hCG on the resumption of meiosis of bovine oocytes surrounded by cumulus cells connected to membrana granulosa. Mol. Reprod. Dev., 45(2): 218-224.

29. Santos Silva, C.T., Wanderley-Teixeira, V., Da Cunha, F.M., De Oliveira, J.V., De Andrade Dutra, K., Navarro, D.M.D. and Teixeira, Á.A.C. (2016) Biochemical parameters of Spodoptera frugiperda (JE Smith) treated with citronella oil (Cymbopogon winterianus Jowitt ex Bor) and its influence on reproduction. Acta Histochem., 118(4): 347-352.

30. Sampaio, I.B.M. (1998) Estatística Aplicada à Experimentação Animal. Belo Horizonte: Fundação de Ensino e Pesquisa em Medicina Veterinária e Zootecnia. p221.

31. Akagi, S., Kaneyama, K., Adachi, N., Tsuneishi, B., Matsukawa, K., Watanabe, S., Kubo, M. and Takahashi, S. (2008) Bovine nuclear transfer using fresh cumulus cell nuclei and in vivo-or in vitro-matured cytoplasts. Cloning Stem Cells, 10(1): 173-180.

32. Mingoti, G.Z., Garcia, J.M. and Rosa-E-Silva, A.A. (1995) The effect of serum on in vitro maturation, in vitro fertilization and steroidogenesis of bovine oocytes co-cultured with granulosa cells. Braz. J. Med. Res., 28(2): 213-217.

33. Bolamba, D., Russ, K.D., Harper, S.A., Sandler, J.L. and Durrant, B.S. (2006) Effects of epidermal growth factor and hormones on granulosa expansion and nuclear maturation of dog oocytes in vitro. Theriogenology, 65(6): 1037-1047.

34. Rao, B.S., Naidu, K.S., Amarnath, D., Vagdevi, R., Rao, A.S., Brahmaiah, K.V. and Rao, V.H. (2002) In vitro maturation of sheep oocytes in different media during breeding and non-breeding seasons. Small Rumin. Res., 43(1): 31-36.

35. Madogwe, E., Tanwar, D.K., Taibi, M., Schuermann, Y., St-Yves, A. and Duggavathi, R. (2020) Global analysis of FSH-regulated gene expression and histone modification in mouse granulosa cells. Mol. Reprod. Dev., 87(10): 1082-1096.

36. Gilchrist, R.B., Ritter, L.J. and Armstrong, D.T. (2004) Oocyte-somatic cell interactions during follicle development in mammals. Anim. Reprod. Sci., 82-83: 431-446.

37. Khan, D.R., Guillemette, C., Sirard, M.A. and Richard, F.J. (2015) Characterization of FSH signalling networks in bovine cumulus cells: A perspective on oocyte competence acquisition. Mol. Hum. Reprod., 21(9): 688-701.

38. Andrade, G.M., Del Collado, M., Meirelles, F.V., da Silveira, J.C. and Perecin. F. (2019) Intrafollicular barriers and cellular interactions during ovarian follicle development. Anim. Reprod., 16(3): 485-496.

39. Fontana, J., Martínková, S., Petr, J., Žalmanová, T. and Trnka, J. (2020) Metabolic cooperation in the ovarian follicle. Physiol. Res., 69(1): 33-48.

40. Younis A.I. and Brackett B.G. (1992) Thyroid stimulating hormone enhancement of bovine oocyte maturation in vitro. Mol. Reprod. Dev., 31(2): 44-51.

41. Hulshof, S.C., Figueiredo, J.R., Beckers, J.F., Bevers, M.M., van der Donk, J.A. and van den Hurk, R. (1995) Effects of fetal bovine serum, FSH and $17 \beta$-estradiol on the culture of bovine preantral follicles. Theriogenology, 44(2): 217-226.

42. Bolamba, D., Russ, K.D., Harper, S.A., Sandler, J.L. and Durrant, B.S. (2006) Effects of epidermal growth factor and hormones on granulose expansion and nuclear maturation of dog oocytes in vitro. Theriogenology, 65(6): 1037-1047.

43. Stocco, C. (2008) Aromatase expression in the ovary: Hormonal and molecular regulation. Steroids, 73(5): 473-487.

44. Krischek, C. and Meinecke, B. (2002) In vitro maturation of bovine oocytes requires polyadenylation of mRNAs coding proteins for chromatin condensation, spindle assembly, MPF and MAP kinase activation. Anim. Reprod. Sci., 73(3-4): 129-140.

45. Lefebvre, C., Terret, M.E., Djiane, A., Rassinier, P., Maro, B. and Verlhac, M.H. (2002) Meiotic spindle stability depends on MAPK-interacting and spindle-stabilizing protein (MISS), a new MAPK substrate. J. Cell. Biol., 157(4): 603-613.

46. Roux, P.P. and Blenis, J. (2004) ERK and p38 MAPKactivated protein kinases: A family of protein kinases with diverse biological functions. Microbiol. Mol. Biol. Rev., 68(2): 320-344.

47. Oseikria, M., Elis, S., Maillard, V., Corbin, E. and Uzbekova, S. (2016) N-3 polyunsaturated fatty acid DHA during IVM affected oocyte developmental competence in cattle. Theriogenology, 85(9): 1625-1634.

48. Del Collado, M., da Silveira, J.C., Oliveira, M.L.F., Alves, B.M.S., Simas, R.C., Godoy, A.T., Coelho, M.B., Marques, L.A., Carriero, M.M., Nogueira, M.F.G., Eberlin, M.N., Silva, L.A., Meirelles, F.V. and Perecin, F. (2017) In vitro maturation impacts cumulus-oocyte complex metabolism and stress in cattle. Reproduction, 154(6): 881-893.

49. Marei, W.F., de Bie, J., Mohey-Elsaeed, O., Wydooghe, E., Bols, P.E. and Leroy, J.L. (2017) Alpha-linolenic acid protects the developmental capacity of bovine cumulus-oocyte complexes matured under lipotoxic conditions in vitro. Biol. Reprod., 96(6): 1181-1196.

50. Sutton, M.L., Cetica, P.D., Beconi, M.T., Kind, K.L., Gilchrist, R.B. and Thompson, J. (2003) Influence of oocyte-secreted factors and culture duration on the metabolic activity of bovine cumulus cell complexes. Reproduction, 126(1): 27-34.

51. Wen, J., Wang, G.L., Yuan, H.J., Zhang, J., Xie, H.L., Gong, S., Han, X. and Tan, J.H. (2020) Effects of glucose metabolism pathways on nuclear and cytoplasmic maturation of pig oocytes. Sci. Rep., 10(1): 2782.

52. Richani, D., Dunning, K.R., Thompson, J.G. and Gilchrist, R.B. (2021) Metabolic co-dependence of the oocyte and cumulus cells: Essential role in determining oocyte developmental competence. Hum. Reprod. Update, 27(1): 27-47.

53. Sieber, M.H., Thomsen, M.B. and Spradling, A.C. (2016) Electron transport chain remodeling by GSK3 during oogenesis connects nutrient state to reproduction. Cell, 164(3): 420-432.

54. Yurowitzky, Y.G. and Milman, L.S. (1972) Changes in enzyme activity of glycogen and hexose metabolism during oocyte maturation in a teleost, Misgurnus fossilis L. Wilhelm Roux Arch. Entwickl. Mech. Org., 171(1): 48-54.

55. Brogan, R.S., MacGibeny, M., Mix, S., Thompson, C., Puttabyatappa, M., VandeVoort, C.A. and Chaffin, C.L. (2011) Dynamics of intra-follicular glucose during luteinization of macaque ovarian follicles. Mol. Cell. Endocrinol., 332(1-2): 189-195.

56. VandeVoort, C.A., Mtango, N.R., Midic, U. and Latham, K.E. (2015) Disruptions in follicle cell functions in the ovaries of rhesus monkeys during summer. Physiol. Genomics, 47(4): 102-112. 